\title{
Discussion on Importance of Two-way Culture in College English Teaching
}

\author{
Ying Zhang \\ Yantai Nanshan University, \\ Longkou, Shandong, China 265706
}

\begin{abstract}
Language and culture are inseparable. Culture cannot be generated without language, and language development changes along with the culture development, the two complement each other. For a long time, because the college English teaching didn't pay attention to the input of Chinese culture, and students' low English language level, the teaching material's lack of Chinese culture and the indifference to expression ability of Chinese culture in English by the society, the output of Chinese culture in English has encountered a lot of obstacles. The viewpoint that we shall pay attention to introduction of western cultural background knowledge, but we shall not ignore the spread of Chinese culture as well has been proposed in this paper, thus to improve the two-way intercultural communicative ability.
\end{abstract}

Keywords-college English teaching; two-way culture; importance

\section{INTRODUCTION}

The so-called culture refers to the sum of total material wealth and spiritual wealth created by human in social and historical practice process from the broad sense. And from the narrow sense, it refers to the social ideology, customs and habits as well as the corresponding social institutions and organizations. Language and culture are inseparable. The American linguistics professor Sapir (Edward Sapir,) said that "There is something behind the language, and language cannot exist without culture." No matter China's rising international status, or the profound Chinese culture that more and more westerners want to learn, or the enhanced awareness of Chinese people themselves, the intercultural communication has transformed from the past one-way communication into today's two-way communication (Jin Huikang: 2001 ). In this new type of intercultural communication, we shall not be limited to express western culture in English, but we shall know how to express the things, ideas, phenomenon etc. (Jiang Yayu, Liu Shiwen 2005) which are unique in Chinese culture in English. Then let more people learn about Chinese culture. However, the Chinese culture and its expression in English expression are basically still in a state of being neglected from a general view of various English teaching in China.

\section{TO THE CHINESE CUlTURAL VocABULARY QUESTIONNAIRE:}

At the end of the semester, the author conducts an impromptu questionnaire survey on part of the non-English major freshmen enrolled in 2015 about the mastering of Chinese culture vocabulary in batches using the break times. Considering the coming of winter vacation, some vocabularies relating to Spring Festival and the most common vocabularies are set. For example: "Spring Festival", "Lantern Festival", "Setting off Fireworks", "Spring Festival Couplets", "Dumpling", "Give new year's greetings", "Red Envelope", "Palace Museum", "Soybean Milk", "Fried Dough Stick" and so on. I had thought the survey results would be satisfied, but on the contrary, the result is worrying. Refer to the table below for detailed information "Table I":

TABLE I. AN IMPROMPTU QUESTIONNAIRE SURVEY ON PART OF THE NON-ENGLISH MAJOR FRESHMEN ENROLLED IN 2015 ABOUT THE MASTERING OF CHINESE CULTURE VOCABULARY

\begin{tabular}{|c|c|c|c|c|c|}
\hline Mocabulary & $\begin{array}{c}\text { Logistics } \\
\text { Management (108 } \\
\text { people) }\end{array}$ & $\begin{array}{l}\text { Marketing(100 } \\
\text { people) }\end{array}$ & $\begin{array}{c}\text { Computer } \\
\text { Science }(78 \\
\text { people) }\end{array}$ & $\begin{array}{c}\text { Engineering } \\
\text { Manage ment ( } 82 \\
\text { people) }\end{array}$ & $\begin{array}{c}\text { Vehicle } \\
\text { Manage ment } \\
\text { (94 people) }\end{array}$ \\
\hline Spring Festival & 80 & 75 & 63 & 56 & 45 \\
\hline $\begin{array}{ll}\text { Setting } & \text { off } \\
\text { Fireworks } & \\
\end{array}$ & 50 & 39 & 30 & 28 & 5 \\
\hline $\begin{array}{ll}\text { Spring } & \text { Festival } \\
\text { Couplets } & \end{array}$ & 2 & 2 & 1 & 1 & 0 \\
\hline Dumpling & 78 & 73 & 68 & 50 & 38 \\
\hline $\begin{array}{l}\text { Give new year' } s \\
\text { greetings }\end{array}$ & 90 & 85 & 65 & 55 & 30 \\
\hline Red Envelope & 2 & 5 & 2 & 1 & 0 \\
\hline Palace Museum & 83 & 85 & 57 & 43 & 5 \\
\hline Soybean Milk & 1 & 1 & 0 & 0 & 0 \\
\hline
\end{tabular}


From the above Table, it is easy to see that (no references are allowed to be used in the whole test process and spelling errors are ignored): the language foundation of the majors of logistics management and marketing is good, they have a relatively good mastering of the surveyed vocabulary, for example, the Spring Festival, Dumpling, Give New Year's greetings and Palace Museum. And mastering of Spring Festival Couplets, Red Envelopes, Soybean Milk and Fried dough sticks is the worst. Surprisingly, what makes us surprise is the expression of Red Envelope, basically all the students write as the "red bag", which expression cannot be understood by foreigners, as they will interpret it as the bag with red color, then they don't know how to reply. The major who has the worst mastering of basic knowledge is vehicle management; they don't know either the basic vocabulary or slightly difficult ones. In the process of test, some students have been in a state of overwhelmed and stunned.

In view of the above results, then I asked a few more questions of cultural knowledge related to the above vocabularies, by chatting (during the breaks or after class or even through QQ), for instance, why does the Spring Festival is also called Guonian? Why do we give Spring Festival greetings to each other? Why do we set off firecrackers? Why do we eat dumplings? What is the origin of Lantern Festival? What do we eat during the Lantern Festival? Is there any activity during the Lantern Festival? What do you know about the Palace Museum? And I found that no matter their mastering of vocabulary or understanding of allusions is worrying. If we cannot master the cultural knowledge which has the most distinctive Chinese characteristics, how can we spread it outside?

\section{FORMATION OF CHINESE CULTURE "APHASIA":}

It can be seen from the survey results that, most of the students has the phenomenon of "aphasia" toward Chinese cultural knowledge. "Aphasia" can be divided into aphasia of native language cultural knowledge and the aphasia of native language culture expression in English. Personally, I think what is more terrible is the aphasia of native language cultural knowledge, which is like a man is "ungrateful" for he has forgotten his roots. And it also like the students will ask me when they saw me that: "Teacher, I want to pass the College English Test Brand 4, what kind of materials should I buy?" My answer is very simple, all the questions will remain essentially the same despite all changes no matter the subject is English or other subjects, you need to make clear all the knowledge in textbook and its supporting extended book no matter it is words or reading, and you need to pay attention to enlarge the quantity of vocabulary. You should not buy the reference materials but to borrow, because you only read the borrowed ones seriously without losing time, as you will be afraid that its owner will get it back immediately. On the contrary, if you have bought your own material, you will feel that you have enough time to read, but finally, you will properly find that your newly bought materials are hardly read. And it is the same in terms of native language culture. Because it is your mother tongue, so you will not spend a lot of time to learn about it, and you always think you know everything naturally. But the reality is the opposite, you probably don't know anything or just know a little. In a test, quite a lot of students don't know the translation of "Kongfuzi" is Confucius, some even translate "Mencius" into "Menxiusi"and translate "A Dream of Red Mansions" into "a story about two girls and a boy", such English is really terrible.

\section{HARM OF Chinese CUlTuRE "APHASiA":}

\section{A. It Has Seriously Hindered the Two-way Communication between Chinese and Western Culture.}

Just as the above mentioned, when foreigners want to know about " A Dream of Red Mansions ", your explanation is still the story about "two girls and a boy", the foreigners will be confused about it, and will be surprised that the Chinese could put such a story as one of " the four great classical novels", as Chinese culture spreader, we will also feel embarrassed, thus hinders further mutual communication.

\section{B. "Aphasia" of Chinese Culture is Not Conducive to the Spread of Chinese Culture.}

As the Chinese people, we are obliged to carry forward our culture, and the direct master of culture shall learn about its essence first of all to get the desired effect. Just like you shall at least have a bucket of water if you want to give students a drop of water, we shouldn't make the foreigners feel that Chinese culture is unattainable, don't let foreigners felt could only dream about Chinese culture, and we cannot leave foreigners with the impression that the Chinese people don't attach importance to their own culture.

\section{Language and Culture are Interlinked.}

Language is a part of culture as a whole, and is the only road of culture generation, development, inheritance and acquisition. So language can reflect all of the history and culture of a nation in detail. The native languages of various nationalities all reflect culture and are influenced by culture. As foreign language learners, we shoulder the responsibility of cultural transmission, and we shall learn more Chinese culture in-depth, to gradually improve the status of Chinese culture, rather than blindly pursue the input of western culture but ignore the output of Chinese culture.

\section{CAuses of Chinese CUlture "Aphasia" (TAKE YANTAI NANSHAN UNIVERSITY AS AN EXAMPLE):}

\section{A. English Learners in China Lack of the Attention to Chinese Culture and its Expression in English, and Lack of the Consciousness of Learning.}

The survey results show that, so far English scholars in China still haven't realized the importance of Chinese culture in English learning, the neglect of their own culture resulting their ignorance of their cultural connotation, even though some know the meaning, they don't know how to express in English. Most scholars believe that learning knowledge in this respect is just for acquisition of knowledge, or for finding a good job, but they do not really realize that learning knowledge in this respect is to promote Chinese culture, and to make China really integrate with the world. At the same time, it also shows 
that most of the students never thought to spread Chinese culture through foreign language learning, making the goal of learning fuzzy or in other words, they haven't evaluated the importance of enhancing the expression of Chinese culture in English on a higher view.

\section{B. Most of the Students' Language Foundation is Very Poor.}

From the questionnaire of Chinese cultural vocabulary we can see that, most of the students have a poor language foundation, especially the students specialized in science \&engineering (vehicle engineering). Although the students specialized in literature and history have a relatively better foundation, their level is uneven, which may be estimated by the English achievements of admission test of part of the students enrolled in 2015. The test time is 90 minutes, with full marks of 100, and questions are relatively simple, with specific scores listed as below "Table II":

TABLE II. THE ENGLISH ACHIEVEMENTS OF ADMISSION TEST OF PART OF THE STUDENTS ENROLLED IN 2015

\begin{tabular}{|l|l|l|l|c|}
\hline Major & $\begin{array}{l}\text { Marketing } \\
(\mathbf{1 0 0} \text { people })\end{array}$ & $\begin{array}{l}\text { Compute } \\
\text { r Science } \\
\mathbf{7 8} \\
\text { people })\end{array}$ & $\begin{array}{l}\text { Engineering } \\
\text { Managemen } \\
\mathbf{t}(\mathbf{8 2} \text { people })\end{array}$ & $\begin{array}{l}\text { Vehicle } \\
\text { Managemen } \\
\mathbf{t} \\
\mathbf{9 4} \text { people })\end{array}$ \\
\hline $\begin{array}{l}\text { Highest } \\
\text { score }\end{array}$ & 93 & 79 & 81 & 74 \\
\hline $\begin{array}{l}\text { Lowest } \\
\text { score }\end{array}$ & 19 & 18 & 11 & 4 \\
\hline $\begin{array}{l}\text { Average } \\
\text { score }\end{array}$ & 53.15 & 52.64 & 38.56 & 32.80 \\
\hline Pass rate & $39.80 \%$ & $40 \%$ & $9.76 \%$ & $11.70 \%$ \\
\hline
\end{tabular}

It can be seen from the data of admission test, the gap between students' English foundation not only exists in students, but also in different majors. In the above four majors, generally, students specialized in marketing and computer science have a better foundation, and the students specialized in engineering management and vehicle management have a very poor foundation, with which foundation, it is difficult to say whether they can pass the final exam, let alone the spreading of the knowledge about Chinese culture. Only a few students can understand the lectures in the same class, which is a great challenge to the teachers.

\section{Students' Weak Purpose of Learning English Leads to the Chinese Culture's Being Neglected in Teaching Process.}

Now most of the students lack of the positive learning attitude as before as they dislike using their brains, and they hope the teachers will provide them with the sorted knowledge. Teachers only set the questions of reading and writing which are relating extra-curricular knowledge considering students foundation. As a result, students have interests in the Chinese culture as supplemented in the class or other extra-curricular knowledge. What's more, some student even say that these knowledge need not to be taught as they won't appear in the exam. Considering students' move like this, teachers have to teach according to students' interests, and to supplement more knowledge to the class with enthusiastic learning interest.
Otherwise, they have to make fewer supplements or even not to make supplement.

\section{The Continuous Decrease of Class Hours Has Resulted in the Neglect of Chinese Culture Spreading in Terms of Teaching Content.}

The series of Experiencing English published by Higher Education Press are adopted for the undergraduates of our college for four consecutive semesters. The maximum total class hours are 320, and 160 now, which are the least (48 class hours for semester 1 and 2, 32 class hours for semester 3 and 4). One textbook is taught each semester, containing 8 units and each unit includes: Lead - fill Spot Dictation; Two dialogues; Two articles with words of around 700, and every article contains exercises such as Words Gap Filling, Phrase Gap Filling and Sentence Translation, Simple Grammar Explanation and Exercises; Writing; Cultural Salon. When making distribution in terms of current class hour, one unit shall be taught in every 6 or 4 class hours, which is impossible. Even the contents in specified in the syllabus cannot be totally taught, let alone to make supplement about or even spread the knowledge of Chinese culture?

\section{MEASURES TO CHANGE CURRENT SituATION:}

\section{A. Change the Traditional Teaching Mode, Pay Attention to} the Spread of Chinese Culture

Both students and teachers should be aware of the importance of Chinese culture in foreign language teaching. Chen Shen (1999) used to say that: for the students, the importance of cultural learning (including native language culture and target language culture) shall be placed higher than the four basic language skills (listening, speaking, reading and writing). Jia Yuxin (1997. 9) thinks that language education should be largely the cultural education. In foreign language teaching, "cultural education" includes native language culture education (home culture education) and the target language culture education (foreign culture education). It is a pity that native language culture education is often neglected in foreign language teaching. We will have difficulty in cultivating and improving students "effective communicative skills" or "twoway communication skills" if we allow this situation to continue. In order to adapt to the trend of the times and to meet the requirements of social development, we should abandon the traditional teaching concept, form the new teaching philosophy, and fully aware of the importance and urgency of native language culture teaching in foreign language teaching.

\section{B. Integrate Chinese Cultural Knowledge with the Syllabus, Textbooks and Curriculum Setting of College English}

At present, the existing syllabus and course requirements has attached certain importance on cultural knowledge, but enough understanding of expressions of Chinese characteristic culture in English hasn't been formed. College students shall learn about western culture in English learning, and they shall also shoulder the task of spreading Chinese culture. As a result, at the stage of college English education, the Chinese culture must be included in the English teaching plan as an essential part, which will be beneficial to the teachers to teach "with 
confidence", and to improve the status of Chinese culture in English teaching, and also can lay a foundation for the students for "two-way communication" in their future work. So why not?

\section{Involve the Mastering Degree of Chinese Culture into Evaluation System}

Test is not only an important means of measuring student learning level and ability, but also an important tool of teachers and students to get feedback. The Chinese culture can be evaluated by procedural examination, and can also by adding Chinese culture contents into the final exam, which can be set to paragraph translation or writing. This will be beneficial to students to learn Chinese culture by making full use of class and extra-curricular time, and can boost the enthusiasm of the teachers to teach Chinese culture, finally can arouse the school and society to pay attention to the importance of Chinese culture in English teaching.

\section{CONCLUSION}

Through a survey on non-English major students about the knowledge of Chinese culture, it can be seen that students' mastering of cultural knowledge and English expression ability are not optimistic. China is a country with five thousand years history and profound cultural connotation. Along with China's economic rise, the two-way intercultural communication will become more common. Teacher shall balance the input of Chinese and western culture to students, instead of caring one thing but lose the other, which is necessity for success cultural communication, and also the demand by the times of cultural integration and complementation in the context of globalization.

\section{REFERENCES}

[1] Jiang Yayu, Liu Shiwen. Methods and Approaches for Improvement of Students' Expressive Ability of Chinese Culture (2005. 3)

[2] Liao Huaying, Chen Feng. Research on the Expression Ability of Chinese Culture in English by Non-English Major Students (2011. 3)

[3] Hu Xiaorong. Research on the Expression Ability of Chinese Culture in English by English Major College Students (2015. 8)

[4] Luo Suqin, Li Xuan. Discussion on "Chinese Culture Aphasia" in English Teaching (2009. 6) 